of its advantages over the traditional sub-Tenon anaesthetic techniques.

\section{Conflict of interest}

The authors declare no conflict of interest.

\section{References}

1 El-Hindy N, Johnston RL, Jaycock P, Eke T, Braga AJ, Tole DM et al. The Cataract National Dataset Electronic Multi-centre Audit of 55,567 operations: anaesthetic techniques and complications. Eye (Lond) 2009; 23: 50-55.

2 Kumar CM, Dodds C. Sub-Tenon's anesthesia. Ophthalmol Clin North Am 2006; 19: 209-219.

3 Allman KG, Theron AD, Byles DB. A new technique of incisionless minimally invasive sub-Tenon's anaesthesia. Anaesthesia 2008; 63: 782-783.

4 Kumar CM, McNeela BJ. Ultrasonic localization of anaesthetic fluid using sub-Tenon's cannulae of three different lengths. Eye (Lond) 2003; 17: 1003-1007.

5 Jeganathan VSE, Jeganathan VP. Sub-Tenon's anaesthesia: a well tolerated and effective procedure for ophthalmic surgery. Curr Opin Ophthalmol 2009; 20: 205-209.

S Lin', RH Ling 1 and KG Allman²

${ }^{1}$ West of England Eye Unit, Royal Devon \& Exeter NHS Foundation Trust, Exeter, UK

${ }^{2}$ Department of Anaesthesia, Royal Devon \& Exeter NHS Foundation Trust, Exeter, UK

E-mail: slin@nhs.net

This work was previously presented at the 44th RANZCO Annual Scientific Congress, November 2012, Melbourne, Australia.

Eye (2014) 28, 497-498; doi:10.1038/eye.2014.14; published online 7 February 2014

Supplementary Information accompanies this paper on Eye website (http://www.nature.com/eye)

\section{Sir,}

Dante and asthenopia: a modern visual problem described during the Middle Ages

One of the oldest descriptions of asthenopia (or eyestrain) may be evidenced in the 'Convivio' ('The Banquet'), a less-known work by the Italian poet Dante Alighieri (1265-1321). It should come as no surprise to find some descriptions of medical problems in Dante's encyclopedic literary works. ${ }^{1,2}$ Indeed, the poet had to be enrolled in the guild of physicians and apothecaries ('ars medicorum et spetiariorum') to take part in the public and political life of Florence; so, although he never practiced medicine, Dante studied the basic principles of science and medicine. ${ }^{3}$ His knowledge on classical optics and human eye functions may be evidenced by accurate descriptions of optical phenomena (eg reflection and refraction) and visual problems (eg presbyopia) in some passages of his masterpiece, the 'Divine Comedy'. ${ }^{3}$ In the 'Convivio', a prose work written between 1304 and 1307, Dante provided with us an accurate description of a sudden visual disorder that he suffered from when he was 27 years old: 'for greatly taxing my sight in eagerness of reading, I so weakened the visual spirits that all the stars appeared to me to be shadowed by a kind of halo' (Conv. 3,9$){ }^{4}$ This description may be referred to asthenopia, a visual disorder that reveals itself through eyestrain, fatigue, pain in or around the eyes, and blurred vision. ${ }^{5}$ Aside from the association with jobs requiring intensive utilization of visual display terminals, its etiology and patho-physiology remain unknown. However, sometimes it appears to be due to specific visual problems such as uncorrected refraction errors or binocular vision problems. ${ }^{5}$ For this reason, some authors postulated that Dante may have suffered from uncorrected hyperopia or astigmatism. ${ }^{3}$ Interestingly, the Italian poet also reported how his own visual disorder was solved, stating that by long repose in dark and cool places, and cooling the body of eye in clear water, I knit together again the disintegrated power, so as to return to my former good condition of sight' (Conv. 3, 9). ${ }^{4}$ All of which is echoed today, and medieval treatment of this condition doesn't seem to be so dissimilar from modern suggestions of ophthalmologists, orthoptists, and visual therapists.

\section{Conflict of interest}

The authors declare no conflict of interest.

\section{References}

1 Widmer DA. Black bile and psychomotor retardation: shades of melancholia in Dante's Inferno. J Hist Neurosci 2004; 13: 91-101.

2 Lucchini RG, Riva MA, Sironi VA, Porro A. Torvis oculis: occupational roots of behavioral neurotoxicology in the last two centuries and beyond. Neurotoxicology 2012; 33: 652-659.

3 Mattioli M. Dante e la medicina. Edizioni Scientifiche Italiane: Napoli, 1965, pp 164-165.

4 Alighieri D. The Convivio of Dante Alighieri. Translated by Philip H Wicksteed, J.M. Dent and Sons: London, 1931.

5 Bhanderi DJ, Choudhary S, Doshi VG. A community-based study of asthenopia in computer operators. Indian J Ophthalmol 2008; 56: 51-55.

\section{MA Riva, C Arpa and M Gioco}

Department of Health Science, University of Milano Bicocca, Monza, Italy

E-mail: michele.riva@unimib.it

Eye (2014) 28, 498; doi:10.1038/eye.2013.313;

published online 10 January 2014 